\title{
Gender Inequality And Its Impact On Economy - A Case Study Muslim Countries
}

\author{
Rummana Zaheer \\ Bilal Hussain \\ Department of Economics \\ University of Karachi
}

\begin{abstract}
There is an immense need for muslim countries to recognize the importance of women especially in education and their well-being in order to establish a prosperous society from economic perspective. A cross-section data of ${ }^{1}$ forty-nine muslim countries was analyzed along with theoretical and empirical explanation of few outlier muslim countries who were economically robust but paradoxically showed low gender-equality profile. The results in few cases showed very different results than expected however those cases in general belonged to oil-rich countries, where their strong economy stands only on the export of oil and its derivatives. The extreme case of Qatar, which has a big per-capita income however its gender inequality profile was comparable to Pakistan, whose per-capita income was only three percent as that of Qatar. Moreover, Saudi Arab's per capita income is ten times more as that of Pakistan but its gender equality profile much less than Pakistan's. Apart from these few cases, the variable explaining the robustness of an economy, roughly regressed negatively with the gender inequality profile, showing that observing gender equality will have positive effects on the economy of muslim countries.
\end{abstract}

Key Words: Gender Inequality, Per Capita Income, Muslim Countries

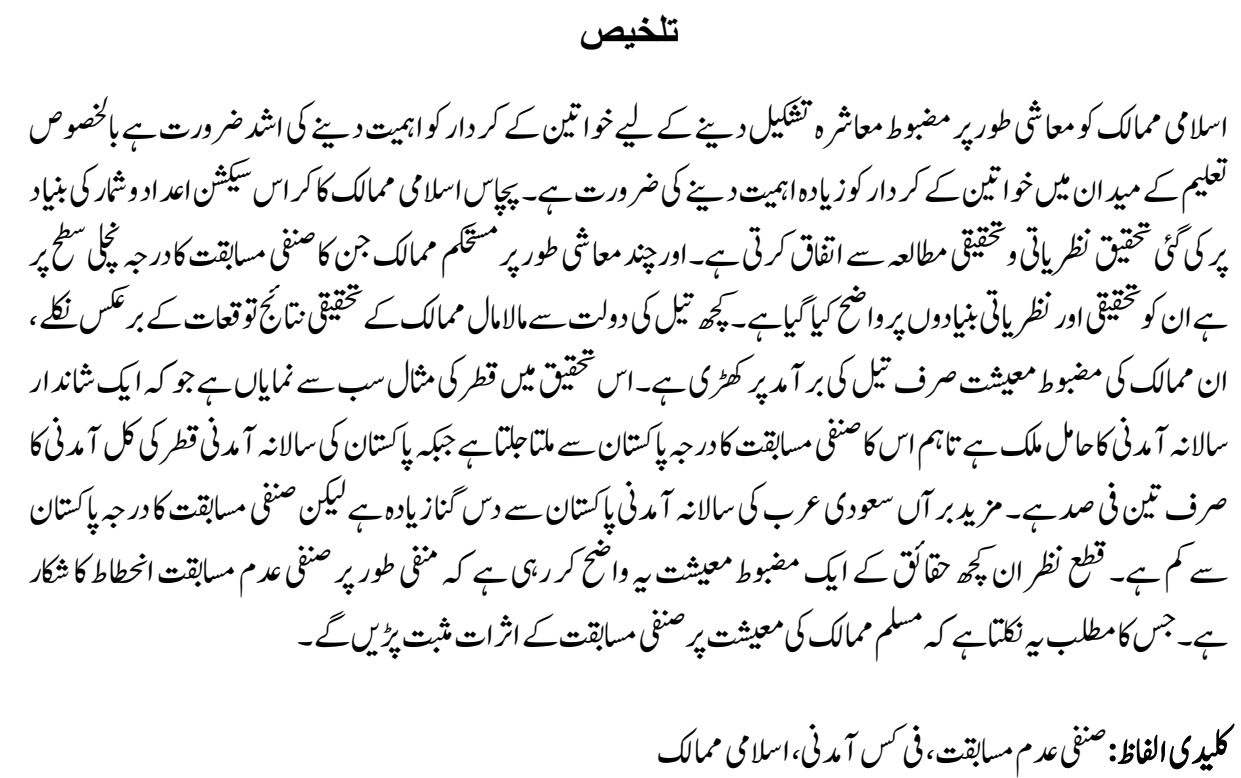




\section{Introduction}

It has been an internationally recognized fact that gender discrimination most importantly in education and health is a big hurdle in establishing a prosperous society. Promoting gender equality not only in education but also in other expects of life has been also made a part of Millennium Development Goals (MDGs) set by United Nations and it is on public policy agenda.

It has been forcefully asserted among contemporary researches that lack of female participation labor force have negative effect on human capital. If a big portion of potential labor force, i.e women, is kept away then overall there human resource present in a country will have a lower quality since many talented and quality labor force participants have been denied inclusion, by one reason or another.

Moreover, the education and health of women has great impact on the off-springs and good health and good education among women would be harbinger of a healthy and comparatively qualified next generation and vice versa.

In this study, cross-section data of all muslim majority countries has been employed to assess whether the muslim countries also exhibits such tendency. The study has employed the dependent variable of per-capita-income, which is adjusted to purchasing power parity in order to reflect the actual ability of the people to access basic goods. The per-capita-income has been used as a proxy to reflect the robustness of economy, since from economic perspective this is the most important variable for households.

Meanwhile, the other variable taken as independent variable, the Gender Inequality Index (GII), shows where a country stands and what profile it possess from gender inequality perspective. GII is a new index developed for measuring gender disparity, which was introduced by the United Nations Development Programme (UNDP) in its 2010 Human Development Report.

Many variables have been incorporated in GII in order to give a status to a country on the basis of quantitative data, showing the well-being of women. This index incorporates reproductive health, education and labor market participation of women, which all supposed to give empowerment to women.

The following chapter gives a thorough review of the other studies' findings on the topic to make a better understanding. Methodology has been described in the third chapter followed by empirical results and conclusion.

\section{Literature Review}

Literature could be found in abundance on the topic since the gender inequality issue has been considered very important from social as well as economic perspective. By reducing gender gap, that is investing more in women, has been stressed in different studies. 
Tembon et al. (2008) writes that gender equality doesn't only imply to the well being of women, but from holistic view, it is an issue of development. It is stressed that women's economic empowerment tends to break vicious cycle of poverty since it helps in economic development, growth, and poverty reduction. The authors further pointed that educating girls and women is of critical importance to economic development. Research conducted in many countries and different regions have proposed that educating girls is one of the most cost-effective ways of initiating development.

Baxter et al. (1995) suggested that female education help to create powerful povertyreducing synergies, which subsequently helps in intergenerational gains. All these effects of female education positively correlate with economic productivity, resilient labor markets, higher income and better societal health and socio-economic well-being.

Pervaiz et al. (2011) analyzed the impact of gender disparity on the economic progress of Pakistan. They studied time series data for the period of 1972-2009. It was found that indeed gender inequality has a noteworthy impact on economic growth of Pakistan.

Ross (2008) focused his gender based study on the Middle East, which has one of the worst gender equality profile. He scaled down other studies, which claimed the region's Islamic traditions, behind the low gender equality. Ross identified that it was actually oil, not Islam, which have this negative impact. Oil production, which is a male dominant industry, reduces the number of women present in the labor force, which eventually reduces their political influence. All these result in atypically patriarchal norms, laws, and political influence.

Galor and Weil (1996) conducted a study to find the relationship between gender gap in education and economic growth. They found that low level of education among women effects in high fertility and eventually low economic growth.

Langerlof (1999) corroborated with results of Galor and Weil (1996) and added that the healthy and educated mothers will have healthy and capable children therefore the education of women will certainly have positive effects on economic growth in present and more prominently in future.

The large gender gap has had big impact on low economic growth of North Africa and Middle East. The argument is bolstered by the fact that when these regions are compared with East Asia, where gender gap is small and economic growth is significant (Klasen, 1999).

But Seguino and Stephanie (2000) found negative relationship between economic growth and women empowerment. They find that one of the factors behind fast economic growth in Asia is due to gender inequality. They suggested that gender wage inequality has stimulating effects on growth. It is because low female wages have attracted investment and inflated exports as unit labor costs get reduced making domestic products cheaper. This subsequently helps in acquiring foreign exchange, which in turn helps in procurement of capital and intermediate goods which raise productivity and growth rates. 
In another study, it was highlighted that in many developing countries, women are largely employed in low-wage jobs such as export-oriented factories and agriculture. They generally excluded from jobs such as construction and retail as these jobs requires heavy labor and contact with men respectively (Anker 1997).

Braunstein and Elissa (2000) argued that women and men share the costs of social reproduction at the household level is a central determinant of women's labor supply and the profitability of investment. The duo found that women have to put more resources at the household level and therefore their productivity as a part of labor force get reduced in comparison with men.

Mason and Smith (2003) observed women's empowerment in the domestic sphere in 56 communities of five Asian countries (India, Malaysia, Pakistan, Philippines, and Thailand). Their analysis found results consistent with the theory. They found that gender relations were heavily influenced by communal norms and values. Therefore community is a much stronger predictor of women's empowerment as compared to individual traits.

However, Rothschild (1983) argued that social status of women can not only be adjudged from macro-level perspective only. Women have the power to derive social status and power from men and also from reproduction. They possess power at the household level even if their status from macro point of view could be quite low. On the other hand, individual women may have little power of decision making at the household level, even if their status at the macro level is high.

\section{Methodology}

This research heavily depends on the Gender Inequality Index (GII), which itself is a combination of several components showing the well being of women in different countries poised against men.

GII is a new index for measurement, which shows gender disparity. The index was introduced in the 2010 Human Development Report, published by the United Nations Development Programme (UNDP).

This research focuses on muslim countries and establishing a relationship between their GII value and the per capita income as an indicator showing economic well being of a country.

\section{Model: \\ Per Capita Income $=$ F $($ GII $)$}

The results are evaluated on the basis of trend they are showing graphically as well as empirically. The data has been inferred with the help of statistical software SPSS. 


\section{Results}

The results of the study go with the trend in other researches and with the theory as Per Capita Income and Gender Inequality Index (GII) value has negative relationship. Which means that as gender inequality rises the per capita income tends to decrease.

\begin{tabular}{|l|l|c|c|}
\hline \multirow{2}{*}{} & & $\begin{array}{c}\text { Correlations capita } \\
\text { income (PPP) }\end{array}$ & $\begin{array}{c}\text { Gender Inequality } \\
\text { Index Value }\end{array}$ \\
\hline \multirow{4}{*}{ per capita income (PPP) } & Pearson Correlation & 1 & $-.353^{*}$ \\
\cline { 2 - 4 } & Sig. (2-tailed) & & .013 \\
\cline { 2 - 4 } & $\mathrm{N}$ & 49 & 49 \\
\hline \multirow{2}{*}{$\begin{array}{l}\text { Gender Inequality Index } \\
\text { Value }\end{array}$} & Pearson Correlation & $-.353^{*}$ & 1 \\
\cline { 2 - 4 } & Sig. (2-tailed) & .013 & 49 \\
\cline { 2 - 5 } & $\mathrm{N}$ & 49 & \\
\hline \multirow{2}{*}{$*$ Correlation is significant at the 0.05 level (2-tailed). } \\
\hline
\end{tabular}

\begin{tabular}{|l|l|l|c|c|}
\hline \multirow{2}{*}{} & \multicolumn{1}{|c|}{ Correlations } \\
\hline \multirow{5}{*}{ Spearman's rho } & $\begin{array}{l}\text { per capita } \\
\text { income } \\
(\mathrm{PPP})\end{array}$ & $\begin{array}{c}\text { per capita } \\
\text { income (PPP) }\end{array}$ & $\begin{array}{c}\text { Gender Inequality } \\
\text { Index Value }\end{array}$ \\
\cline { 2 - 5 } & Sig. (2-tailed) &. & $-.716^{* *}$ \\
\cline { 2 - 5 } & $\mathrm{N}$ & 49 & .000 \\
\cline { 2 - 5 } $\begin{array}{l}\text { Gender } \\
\text { Inequality } \\
\text { Index Value }\end{array}$ & Correlation Coefficient & $-.716^{* *}$ & 49 \\
\cline { 3 - 5 } & Sig. (2-tailed) & .000 & 1.000 \\
\cline { 2 - 5 } & $\mathrm{N}$ & 49 & 49 \\
\hline **. Correlation is significant at the 0.01 level (2-tailed). \\
\hline
\end{tabular}

The following graph elaborately shows a negative relationship of per capita income and GII value. Few outliers could easily be identified, which have high per capita income and high corresponding GII value. It could be ascertained that there is some other important factor positively affecting the high per capita income and the impact of the independent variable of this study has been sidelined. 


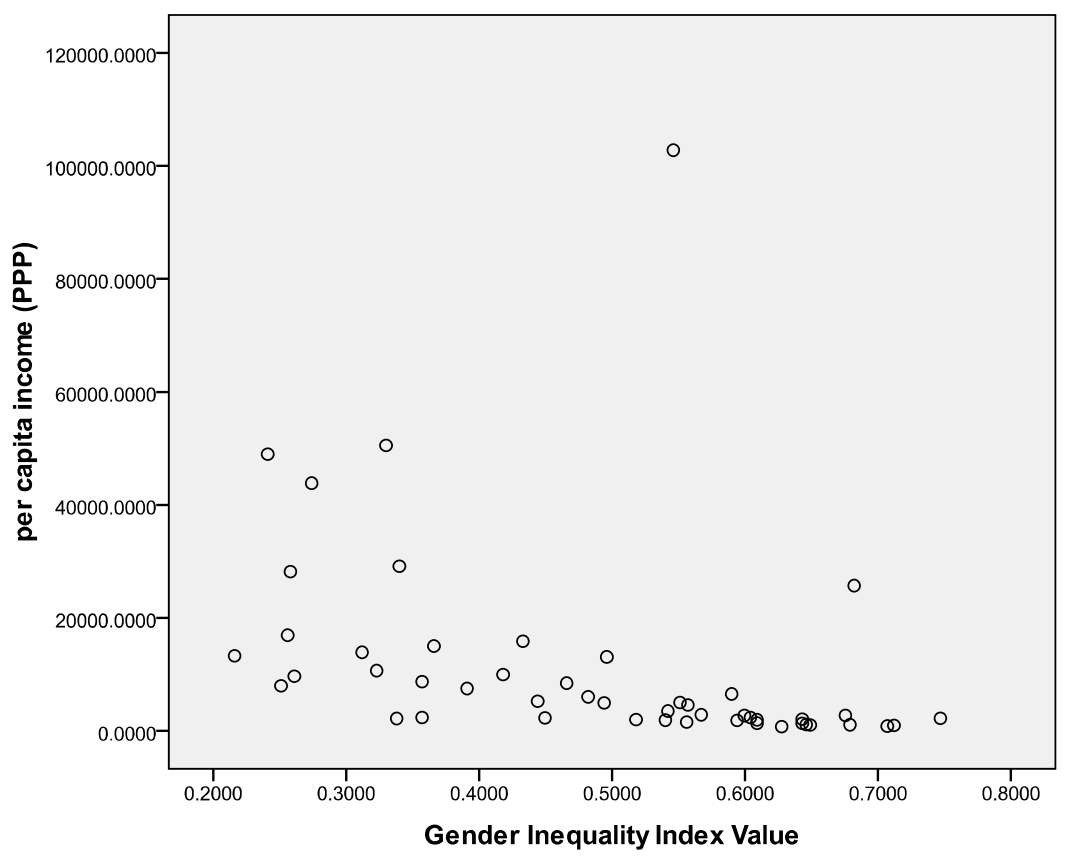

Such outliers have had a negative impact on the results of our study. However, since these outliers have been identified, it will be easier to understand their negative impact and evaluate the results of the study after incorporating the understanding of the outliers.

Model Summary

\begin{tabular}{|l|c|c|c|c|}
\hline Model & $\mathrm{R}$ & $\mathrm{R}$ Square & $\begin{array}{c}\text { Adjusted R } \\
\text { Square }\end{array}$ & $\begin{array}{c}\text { Std. Error of the } \\
\text { Estimate }\end{array}$ \\
\hline 1 & $.353^{\mathrm{a}}$ & .124 & .106 & $1.7036212 \mathrm{E} 4$ \\
\hline \multicolumn{2}{|c|}{ a. Predictors: (Constant), Gender Inequality Index Value } \\
\hline
\end{tabular}

The R-Square, which shows the robustness of the relationship of the variables, is over 12 percent. However, this figure had been bigger if we had eliminated the outliers.

\section{Conclusions}

In this study, an attempt was made to find whether the indicators showing the well-being of women have a positive impact on the economy of Muslim countries. It has been found that indeed the well-being of women has a positive relationship with the economy. As the health, literacy rate, and labor force participation of women improves in a country that country's economy will also tend to improve.

Looking at the graph, many countries, showing a divergence from expected results, could be identified. The most extreme cases are that of Qatar, which has the biggest per capita 
income among Muslim countries, and Saudi Arabia which also has big per capita income but both shows very high value of gender inequality index.

There are also few more countries whose GII profile is high but their per capita income is also high. However, there is one common thing between them, that is their high per capita income is mainly due the fact that they are oil-rich countries.

\section{Discussion}

The well-being of women, in terms of health and education would have a positive impact on the health and education of the next generation. Over the years, this positive impact will accumulate into a much better society from economic as well as some other perspective. But since our focus is economy, the understanding of the research will focus on that only. As more girls and women get education and become a part of labor force, the country tends to become more productive since labor force rises in technical, skilled and unskilled participation.

Moreover, for a given number of jobs, there would be increased number of candidates and merit tends to rise of employees. This would initiate more competition and hence more efforts from potential candidates, therefore increasing the overall ability of individuals of labor force. All these would eventually result in better economic output.

\section{Implications}

This research will be helpful for people to understand the importance of the well-being of women from health, education and labor force participation perspective. Since, Muslim countries have been the focus of the study, this study would help to understand the importance of women, apparently sidelined in a Muslim society. Female candidates should also be given equal importance in educational enrolments and more importance in health.

\section{Future Researches}

The variable of Gender Inequality Index (GII) used in this study, does not incorporate regional realities. For example, mortality rate of women during child birth or mortality rate of a country could be high its corresponding mortality rate of men could also be high in the same way. So it is the problem of the country and not gender inequality as a whole. Moreover, fertility rate is not considered as a negative issue among Muslims so therefore few variables incorporated in GII have neglected regional realities.

Therefore, the researcher suggests that in future the GII value should be re-adjusted to incorporate such regional factors to have a better understanding of the relationship gradients of the variables of this study.

\section{End Notes}

1. The forty-nine countries taken in this study have significant Muslim population and most of the countries have Muslim majority. The countries considered have been named in the Appendix section. 


\section{References}

Anker, R. 1997. Theories of occupational segregation by sex: An overview. International Labour Review 136 (Autumn): pp. 315-39.

Baxter, Janeen and Emily W. Kane (1995). Dependence and independence: A crossnational analysis of gender inequality and gender analysis. Gender and Society vol. (9): pp. 193-215.

Braunstein, Elissa. 2000. Engendering Foreign Direct Investment: Household Structures, Labor Markets, and the International Mobility of Capital. World Development vol. 28 (7): pp. 1157-72.

Galor, O. and D.N. Weil, (1996). The Gender Gap, Growth: Fertility and Growth. American Economic Review, vol. 86 (2): pp. 374-87.

Klasen, S., (1999). Does Gender Inequality Reduce Growth and Development? Evidence from Cross-Country Regressions, Policy Research Report, Engendering Development, Working Paper No. 7. World Bank, Washington, D.C.

Lagerlof, N., (1999). Gender Inequality, Fertility and Growth, University of Sydney, Department of Economics, Australia.

Mason K.O. and Smith H.L., (2003). Women's Empowerment and Social Context: Results From Five Asian Countries. World Bank

Pervaiz Z., Chani M.I., Jan S.A., and Chaudhary A.R. (2011). Gender Inequality and Economic Growth: A Time Series Analysis for Pakistan. Middle-East Journal of Scientific Research, vol. 10 (4): 434-439, 2011.

Ross M., (2008). Oil, Islam, and Women. American Political Science Review, vol. 102, (1).

Safilios-Rothschild, Constantina. (1982). Female power, autonomy and demographic change in the Third World, In Women's Roles and Population Trends in the Third World, ed. Richard Anker, Mayra Buvinic, and Nadia H. Youssef. London: Croom Helm, pp. 117-132.

Seguino, Stephanie, (2000). Accounting for Gender in Asian Economic Growth, Feminist Economics, vol. 6 (3): pp. 27-58.

Tembon, F. Mercy and Lucia (2008). Girls' Education in the 21st Century: Gender Equality, Empowerment, and Economic Growth. Open Knowledge Repository, The World Bank.

World Bank, 2001. World Development Report: Attacking Poverty. Washington DC: The World Bank. 


\section{Appendix}

\section{Correlations}

\begin{tabular}{|l|l|c|c|}
\hline \multirow{2}{*}{\begin{tabular}{l}
\multirow{2}{*}{$\begin{array}{l}\text { per capita income } \\
\text { (PPP) }\end{array}$} \\
Sender Inequality
\end{tabular}} & $\begin{array}{c}\text { per capita } \\
\text { income (PPP) }\end{array}$ & $\begin{array}{c}\text { Gender Inequality } \\
\text { Index Value }\end{array}$ \\
\cline { 2 - 4 } \begin{tabular}{l} 
Index Value \\
\cline { 2 - 4 }
\end{tabular} & Sig. (2-tailed) & 1 & $-.353^{*}$ \\
\cline { 2 - 4 } & $\mathrm{N}$ & 49 & .013 \\
\cline { 2 - 4 } & Sig. (2-tailed) & $-.353^{*}$ & 49 \\
\cline { 2 - 4 } & $\mathrm{N}$ & .013 & 1 \\
\hline *. Correlation is significant at the 0.05 level (2-tailed). & 49 \\
\hline
\end{tabular}

\begin{tabular}{|c|c|c|c|c|}
\hline & & & $\begin{array}{c}\text { per capita } \\
\text { income }(P P P)\end{array}$ & $\begin{array}{l}\text { Gender Inequality } \\
\text { Index Value }\end{array}$ \\
\hline \multirow{6}{*}{$\begin{array}{l}\text { Spearman's } \\
\text { rho }\end{array}$} & \multirow{3}{*}{$\begin{array}{l}\text { per capita } \\
\text { income } \\
(P P P)\end{array}$} & Correlation Coefficient & 1.000 & $-.716^{\text {*** }}$ \\
\hline & & Sig. (2-tailed) & . & .000 \\
\hline & & $\mathrm{N}$ & 49 & 49 \\
\hline & \multirow{3}{*}{$\begin{array}{l}\text { Gender } \\
\text { Inequality } \\
\text { Index Value }\end{array}$} & Correlation Coefficient & $-.716^{* *}$ & 1.000 \\
\hline & & Sig. (2-tailed) & .000 & . \\
\hline & & $\mathrm{N}$ & 49 & 49 \\
\hline
\end{tabular}

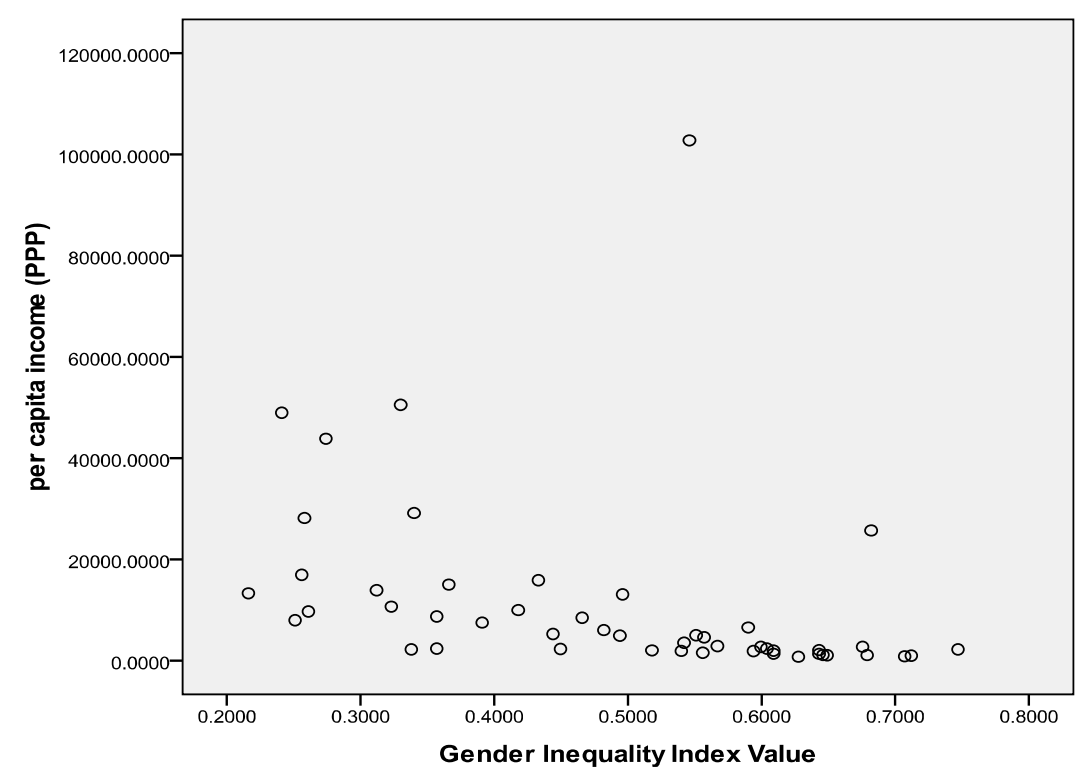




\section{Model Summary}

\begin{tabular}{|l|c|c|c|c|}
\hline Model & $\mathrm{R}$ & $\mathrm{R}$ Square & $\begin{array}{c}\text { Adjusted R } \\
\text { Square }\end{array}$ & $\begin{array}{c}\text { Std. Error of the } \\
\text { Estimate }\end{array}$ \\
\hline 1 & $.353^{\mathrm{a}}$ & .124 & .106 & $1.7036212 \mathrm{E} 4$ \\
\hline
\end{tabular}

a. Predictors: (Constant), Gender Inequality Index Value

Dr. Rummana Zaheer is Assistant Professor in the Department of Economics, University of Karachi.

Bilal Hussain is M. Phil Student in the Department of Economics, University of Karachi. 